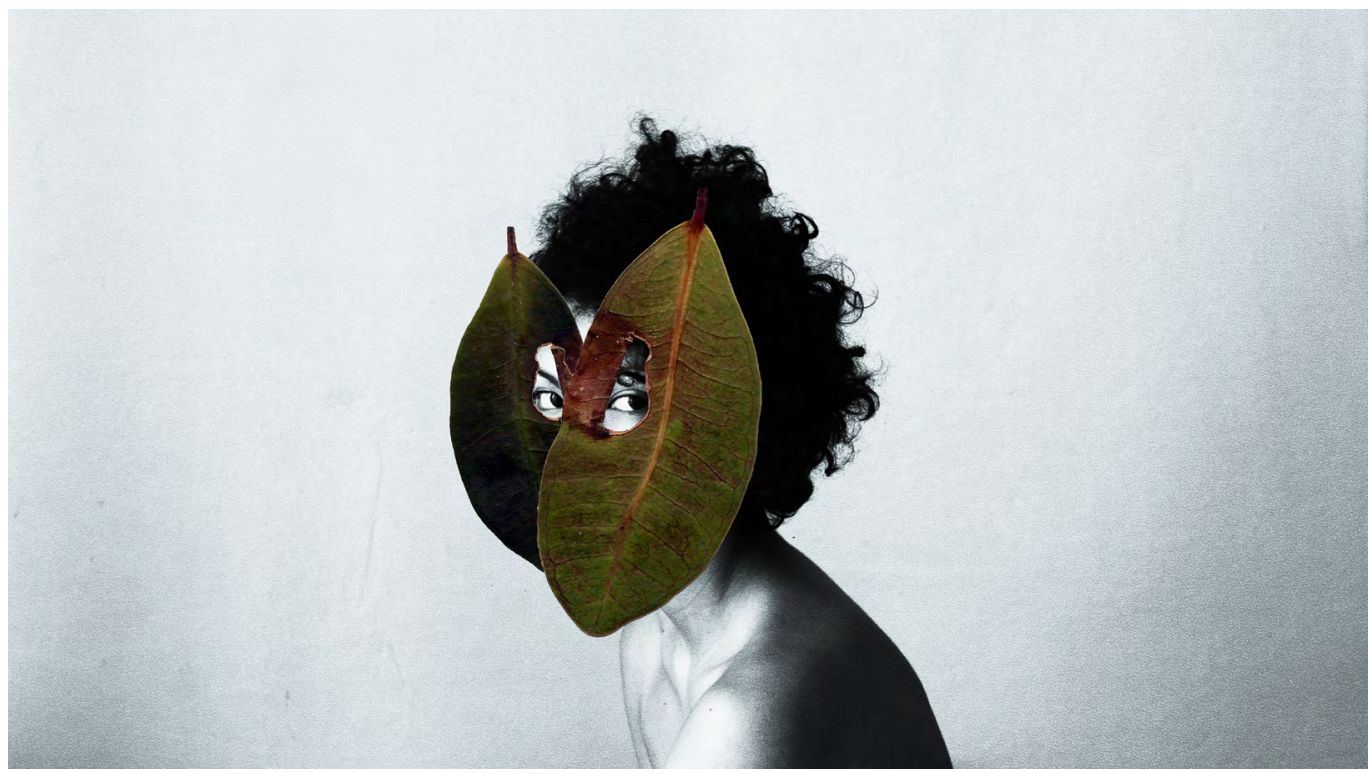

\title{
On Silence and the Reestablishment of Non-Western Connections
}

PC: (CC) @silenceeffects, on Flickr.com.

\section{Dušica RISTIVOJEVIĆ}

was born in the Socialist Federal Republic of Yugoslavia, in present-day Serbia, just in time to live through and remember the final years of Yugoslav socialism and the many faces of its afterlife. What I want to be very open about is the central role my personal experiences and academic knowledge about three key issues have played in what I do, think, and feel about Chinese social activism, self/censorship, and feminist scholarship. These issues are democratisation and post-socialist transformations; problems related to the creation and dissemination of popular and academic knowledge in and on socialist and post-socialist contexts; and the ways in which many layers of unequal power relations emerge from and influence transnational academic and activist encounters.

I see myself as a socially engaged researcher, teacher, and activist who analyses and experiences the ways in which global political currents influence social organising in China and other post-socialist spaces. I also see myself as someone who prefers to stay out of the spotlight while using the spaces made possible through academia to help organise and facilitate activist meetings and events. In both efforts, I am a relative latecomer to anglophone Western academia and its canonised 
knowledge in Chinese and gender studies, which makes me very conscious of and very cautious about the inclusionary and exclusionary processes in these fields.

My research on Chinese activism and feminism starts in late-Qing China and comes up to the present, mostly focusing on the visions and actions of transnationally linked Chinese actors and their international allies during two ground-shaking periods of China's repositioning in the modern world order: the late-Qing reforms and the post1989 period. For several years, I have also been collecting material about the All-China Women's Federation (ACWF), especially its engagements in global feminist networks and its role in China's foreign policy and diplomacy. In all this work, silence, in various guises, has been prevalent and as important as utterance.

\section{Silences}

Much of the discussion about self-censorship in Chinese studies implies, in a rather critical way, that we all-as learning, writing, speaking, and acting subjects-are succumbing either to the requests from a controlling power or to our own opportunistic calculations. In my view, these insinuations do not sufficiently engage with the ways in which we are not all fully and equally unconditioned individuals; our agency is formed and practised in several different ways, and we do not all possess the same space for action and resistance. From where I stand, it is clear our silences are related in much more complex ways to our different positions within the academic, activist, ideological, or sociopolitical contexts we inhabit. When it comes to my research, there have been many different reasons to be silent.

I decided, for instance, not to write an article about the dynamics of organising and conducting an international collaborative workshop because I could not figure out how to include in the analysis several critical situations without endangering the affective and professional relations among the scholars and activists who participated in the workshop, who were exceptionally important in the feminist academic and activist community. At the same time, I was a junior scholar in a precarious academic position, just entering a relatively well-established, tightly knit, and closed Nordicbased China-related gender research community, and I worried that writing on this topic would quickly close various slightly open doors for future collaboration.

Another kind of silence has been linked to the theoretical aspect of my academic engagement. The best example is my decision not to publish an article I had written after I received a review in which I was called a 'Chinese nationalist' because my analysis supposedly implied that I think China should have more power in international politics, regardless of its violation of human rights. This evaluation was completely devoid of merit as my paper was using empirical evidence to clearly and simply point out how reports of five young imprisoned Chinese activists became part of a critical discursive repertoire on the Chinese Communist Party and the Chinese Government, and how this inclusion of Chinese feminism accelerated the ongoing struggles over the dominance of global geopolitical, economic, and symbolic structures by Western political actors. To this day, being labelled a 'Chinese nationalist' has prompted me to remain silent until I feel I am able to respond and articulate more clearly my criticisms of both Western neo-imperialist and Cold War-resonant logic and approaches and China's nationalist, xenophobic, neo-imperialist discourses and undertakings. Unfortunately, the current high-voltage polarisation and rendering of black and white positioning have made it impossible for me to think through my own critical stances openly and in dialogue with others.

Yet, the recurrent and perhaps most important reason for my silence has been a common politics and the joint agreement between me, my collaborators and friends, and the actors I am writing about in my research projects. Here I am thinking about what has been addressed in anthropology as ethnographic refusal as a research method (see, for example, Tuck and Yang 2014). This method asks for our responsible engagement with the politics 
of how data are represented, strongly emphasising the importance of keeping certain types of research data out of the public gaze.

This line of thinking about the consequences of revealing research findings is the main reason I decided, for example, not to write about the findings related to the regional support networks of activists from Taiwan, Hong Kong, and China. As one of my closest collaborators and friends warned me at the end of one year of ethnographic and archival work, if I published my research findings and publicly talked about where, what, and how the activists from the region worked together, my work could easily be used for nefarious purposes. One example of this, I was warned, was a report produced by a Taiwanese citizen who worked for the Chinese Government by collecting publicly available information about the activities and connections between Taiwanese activists and their China-based collaborators. This report, my collaborator insisted, was then used in a Chinese court case as proof of the criminal activities of a Chinese activist who was visiting Taiwan.

This was the way my collaborator conveyed to me the content of a much-referenced statement by Eeling Chiu, General Secretary of the Taiwan Association for Human Rights. Commemorating the third anniversary of the 709 Crackdown-a nationwide action by Chinese police that started on 9 July 2015 and saw human rights lawyers and activists jailed, disbarred, or placed under surveillance-Ms Chiu stated that several Taiwanese people

are suspected of being attracted and gathered by the Chinese authorities to collect records of the words and activities of the members of Chinese civil society visiting Taiwan. [These Taiwanese citizens] participated in the conference activities of Chinese overseas civil movement organisations in Taiwan, recorded the contents of the event, and handed over the recordings to the Chinese authorities. (Chiu 2018)

As Ms Chiu asserted, in a case related to the 709 Crackdown, these records were used as 'the prosecution evidence of the Chinese authorities, resulting in lawyer Zhou Shifeng and $\mathrm{Mr} \mathrm{Hu}$ Shigen being sentenced to seven years and seven and a half years of heavy punishment for the crime of "subversion of the state power"' (Chiu 2018).

My collaborator-himself a well-known initiator of and participant in meetings between Taiwanese and Chinese civil society organisations-suggested I not use any of the data I gathered through my participation in their meetings and private and public discussions. I was aware that scholars whose research focuses on Chinese nongovernmental organisations active in sensitive fields employ various methods to overcome the risks to research subjects, such as providing anonymisation of research findings and discussion of the issues related to Chinese civil society beyond the regulatory/policy dimension. However, I could not find an effective way to anonymise the activities of well-known organisations and individuals whose public work would be easily identified. Cases such as these highlight the ethical imperative of silence in certain situations.

\section{The Silent Academy}

Silence in academia has a high price, both for the scholar who does not put her knowledge and activities on public display and in terms of the threat of erasure of unrecorded, unanalysed, and unacknowledged actors, situations, and processes.

Despite its numerous downsides, hypocrisies, and confines, academia offers respectability, connections, and symbolic, cultural, and social capital, which may be used not only for developing and practising socially transformative pedagogies, but also for obtaining and delegating space for activists to use for their causes. If academia is understood and practised in this way, a position in the academy is worth fighting for; but to acquire an academic position without publications and publicity for one's actions is very hard. Hence, while I focus on small-scale public talks, lectures, and closed discussions when it comes to activism research, I am also working simultaneously on several additional research topics and trying to 
build my publication record. This is not a sustainable situation but is one potentially worth the effort to be able to facilitate crucial spaces for my activist collaborators.

At the same time, the threat that a present-day scholar's silence poses of burying and obliterating activist interventions is particularly disturbing. As a researcher of history, I often think about the distinct respect and weight that history writing has in Chinese cultural contexts, as well as the admirable and at times deeply moving devotion of Chinese women and feminists to recording and recognising their past and present struggles and accomplishments. Current limitations on access to archives, as well as numerous obstacles to engaging with socially concerned scholars and activists in China, make it very important to think about workarounds for gathering and preserving knowledge about the past and present, which may be politically useful for feminists and activists.

For a great part of my research on Chinese feminist and activist networks, the best way to proceed is to collect the sources and wait. With the support of senior feminist scholars and activists who have been pivotal in bringing together Chinese and internationally based feminists in collaborative networks, I have been collecting published and unpublished written sources, interviews, and textual and visual ethnographic notes. Ethically, all I can do is wait for the right time to publicly relate the history of the events and persons I am following-a history that must be told. However, there are parts of my research that may tease out our thinking about what can be done now. What kind of engagements with 'big politics' are possible and what spaces for manoeuvring may be opened if we look at contemporary politics through the lens of feminist history?

\section{Working through the Present Moment}

As I learned through my research, long-term historical observation of feminism in China reveals not only its strong interdependence on, and deep embeddedness in, local intellectual, social, and political traditions and experiments, but also its persistent openness, curiosity, engagement, and commitment to transnational and transcultural feminist connections, solidarity, and support networks. These networks-since their earliest formations in the late Qing period, through the socialist internationalist connections that peaked in the 1950s, to the Fourth World Conference on Women in Beijing in 1995, and its aftermath-have been heavily influenced by international politics. At present, escalated tensions between China, the United States, and Western European countries arguably complicate not only the local dynamics of Chinese feminist spaces, but also transnational feminist support and solidarity networks and collaborative endeavours. Transnational feminist and women's rights networks created in the wake of the 1995 Women's Conference and actively supported by international foundations and governmental and nongovernmental organisations have been playing a decisive role in informing and directing both transnational and domestic engagements with Chinese feminisms in recent decades. But new opportunities for collaborations with Chinese feminism may be offered by decentring and moving beyond China-West relations, as well as the establishment-or, in a longer historical frame, the reestablishment-of the connections between Chinese and non-Western feminists. For lack of a better term, I use here 'non-Western' to include what is addressed today as the Global South as well as the former Central and Eastern European socialist 'Second World' and the member states of the Non-Aligned Movement.

The revival of and focus on the former Second World and Non-Aligned Movement links play a substantial role in the processes of China's geopolitical, economic, and symbolic repositioning in global politics and the global economy. China increasingly directs its capital and its soft power to the regions that had or have discontent with the West. Within this globally diverse process, China often approaches post-socialist areas in particularly intelligent, friendly, and respectful ways, and places 'people-to-people exchange' at the core of its proclaimed values and diplomatic aims. The unassuming space of this exchange may offer the opportunity for feminists to come together. 
The state-sanctioned women's rights space inhabited by the ACWF and its public narratives on transnational and transcultural links point to this non-Western space, which is allowed and even encouraged. At the end of 2019, I conducted a set of ethnographic visits to the state-funded Chinese Museum of Women and Children in Beijing, which was established in 2010 and curated by the ACWF. I was interested to read the way in which the ACWF curated the space and interpreted it as a unique insight into what is possible, what is achievable, and what is allowed to be said about the past and women's lived realities in contemporary China.

I was especially interested in the Hall of International Friendships-the space where a narrative about the international engagements of Chinese women has been created through several mediums. Especially telling is the choice of gifts displayed. Mostly handicrafts and artefacts, received from all over the world, these gifts are intended to symbolise the mutual respect and close connections between China and the gifting countries, whereas the selection of items for display may be read as signalling the international connections Chinese women are permitted or encouraged to enjoy and foster. The gifts, as well as textual and visual messages, mirror the wider geopolitical picture: the West is not the location of desired relations. Instead, links with African, Asian, and former Soviet and post-socialist European countries dominate the material 'friendship' narrative.

In a way, to connect and reconnect with non-Western feminists would be a continuation of historically documented but insufficiently analysed truly global Chinese feminist exchanges. In June 2019, Professors Wang Zheng, Elisabeth Armstrong, and Kristen Ghodsee-three scholars who are researching post-socialist women's movements-organised the Global Socialist Feminism Symposium at the University of Michigan. During the four days of the symposium, scholars and activists from and/or working on histories of post/ socialist women's organisations in China, India, Bulgaria, Zambia, Poland, Vietnam, the former Yugoslavia, and Algeria discussed the erasure of rich histories of the experiences of women from the Second World and their unrecorded and therefore un-theorised collaborations with and contributions to the improvement of women's lives globally from the canon of transnational feminist literature. Our conversations stressed the need for more complex reflections on the marginalisation of socialist-state feminisms in Western/Northern academia and the relations of these processes to what Francisca de Haan (2010) called 'continued Cold War paradigms'.

The dynamics of the continued or renewed Cold War relationalities-with their ensuing logic, sentiments, and unequal access to resourceshave been significantly influencing the ways in which activists and academics come together. It is a great irony that the Chinese state's increased use of national and international power to influence, control, and restrict the activist space also offers immense potential for activating and reactivating overlooked and neglected communicative and collaborative activist and academic venues outside the Western and Northern centre. These spaces may be used not only to address the largely unfamiliar commonalities of the experiences and strategies of non-Western activists and feminists from different yet similarly burdened locations, but also to set the stage for long overdue work on equalising the power relations among feminists globally. 
This text is taken from Made in China Journal: Volume 6, Issue 2, 2021, edited by Ivan Franceschini and Nicholas Loubere, published 2021 by ANU Press, The Australian National University, Canberra, Australia.

doi.org/10.22459/MIC.06.02.2021.25 